\title{
Self-reported habits regarding dental bur use and conditioning among academic and non-academic argentinian dentists
}

\author{
Hernan J. Tartacovsky', Veronica A. Ciparelli', Lucia J. Horvath', Martin Garcia-Cuerva', \\ Sebastian Tortoni', Maria E. Iglesias²
}

1. Universidad de Buenos Aires. Facultad de Odontología. Cátedra de Odontología Restauradora, Buenos Aires, Argentina.

2. Universidad de Buenos Aires. Facultad de Odontología, Cátedra de Materiales Dentales, Buenos Aires, Argentina

\begin{abstract}
The removal of tissues affected by caries lesions is one of the most frequent procedures in daily dental practice. The aim of this study was to collect information about the habits of members of the academic and non-academic dental community in Argentina regarding the use and conditioning of burs employed in the removal of dentin during the treatment of carious lesions. A 14item questionnaire was prepared, and once validated in small groups, it was sent to three lists of dental subscribers through the computer services area of the School of Dentistry, University of Buenos Aires, Argentina (FOUBA). By the deadline for receiving responses, which was set as four weeks after the sending date, 294 replies were received. Results: percentage (95\%CI): $47.93 \%(42.18-53.68 \%)$ of the respondents were faculty members, of whom $37.24 \%$ (31.68-42.81\%) claimed to belong to FOUBA. Of the respondents, $26.90 \%$ (21.79-32.00\%) reported being under 35 years old, 37.59\% (32.01-43.16\%) 36 to 45 years old, $22.07 \%(17.30-26.84 \%) 46$ to 55 years and $11.38 \%(7.72-15.03 \%)$ over 55 years. Regarding bur type, $68.07 \%(62.31 \%-73.44 \%)$ claimed to use round burs to remove carious dentin and $27.72 \%(22.60 \%-23.31 \%)$ round + others.
\end{abstract}

Regarding rotary speed, $22.07 \%$ (17.30-26.84\%) use medium speed, $32.76 \%$ (27.36-38.16\%) use high speed, and $32.76 \%$ (27.36-38.16\%) use medium + super high. Only 17.93\% (13.52$22.35 \%)$ indicated that they know how to quantify the number of times they use their burs, while 50.34\% (44.59-56.10\%) of the respondents said that they use burs "until they no longer cut", $23.79 \%$ (18.89-28.69\%) use them 1 to 5 times. $98.27 \%$ (96.77-99.77\%) said they clean their burs once used. When the answers regarding the use of rubber dam were compared with area of specialization (Chi-square), it was found that faculty members mention the use of burs under rubber dam always or almost always $74.82 \%$ (67.60-82.04\%) while outside the academic field, $51.01 \%$ (42.98-59.03\%) of dentists say that they never or almost never do so $(p<0.001)$. Conclusion: Most respondents state that they sterilize their rotary instruments in some way after use. About half of them do not keep track of the number of uses and use burs "until they no longer cut". Received: September 2020; Accepted: October 2020.

Keywords: dental instruments - disinfection - sterilization - surveys and questionnaires.

\section{Autoreporte sobre hábitos de uso y acondicionamiento de fresas de odontólogos argentinos en ámbitos académicos y no académicos}

\begin{abstract}
RESUMEN
La eliminación de los tejidos afectados por las lesiones de caries es uno de los procedimientos más realizados en la práctica diaria de la odontología. El objetivo de este estudio fue recolectar información acerca de los hábitos de miembros de la comunidad odontológica de la Argentina en cuanto a la selección, utilización y acondicionamiento de fresas para la remoción de dentina en el tratamiento de lesiones cariosas. Se elaboró un cuestionario de 14 reactivos que fue validado en pequeños grupos. Una vez definido el formato final se lo envió a tres listas de suscriptores odontólogos a través del de área de Informática de la Facultad de Odontología de la Universidad de Buenos Aires (FOUBA). El plazo para la recepción de respuestas se estableció en cuatro semanas luego del cual se obtuvieron 294 réplicas. Resultados: porcentaje (IC95\%), el 47,93\% (42,18-53,68\%) eran docentes, de los cuales el 37,24\% (31,68-42,81\%) afirmó ser docente de la UBA. El 26,90\% (21,79-32,00\%) refirió te-
\end{abstract}

ner menos de 35 años, el 37,59\% (32,01-43,16\%) entre 36 y 45 años, el 22,07\% (17,30-26,84\%) entre 46 y 55 años y el 11,38\% (7,72-15,03\%) más de 55 años. El 68,07\% (62,31\%-73,44\%) afirmó utilizar fresas redondas y el 27,72\% (22,60\%-23,31\%) redondas + otras. En cuanto a la velocidad utilizada: media velocidad: $22,07 \%$ (17,30-26,84\%), superalta: $32,76 \%(27,36-$ $38,16 \%)$, media + superalta: $32,76 \%(27,36-38,16 \%)$. Sólo el $17,93 \%(13,52-22,35 \%)$ indicó que sabe cuantificar la cantidad de usos que les dan a sus fresas, en tanto que el 50,34\% (44,59$56,10 \%)$ de los consultados afirmó que utiliza las fresas "hasta que no corten más", el 23,79\% (18,89-28,69\%) le da entre 1 y 5 usos. El 98,27\% (96,77-99,77\%) afirmó que limpia sus fresas una vez utilizadas. Cuando se contrastaron las respuestas respecto al uso de aislamiento con el área de desempeño (Chi-cuadrado) se encontró que los docentes refieren utilizar las fresas con aislamiento absoluto siempre o casi siempre $74,82 \%(67,60-82,04 \%)$ mientras que fuera del ámbito acadé- 
mico el 51,01\% (42,98-59,03\%) respondieron que nunca ó casi nunca lo hacen $(p<0,001)$. Conclusión: la mayoría afirma que acondiciona de alguna manera el instrumental rotatorio luego de su uso, alrededor de la mitad no lleva registro del número de usos y sostiene que utiliza las fresas "hasta que no cortan más".

Palabras clave: instrumentos dentales - desinfección - esterilización - encuestas y cuestionarios.

\section{INTRODUCTION}

The removal of caries-affected tissues is one of the most frequent procedures in daily dental practice. The aim of using different combinations of speed, pressure and type of cutting instrument is to achieve maximum cutting power without causing biological damage to the pulp. The hydroxyapatite in the dentine is a fragile material, so it requires less energy to produce fracture, while the collagen matrix is a soft material and the way it is cut is guided by different principles, like those of ductile materials. Although this maneuver can be performed using either manual or rotary instruments, the literature currently recommends the use of plain cut round burs, whose size is chosen in relation to the size of the lesion at low, medium or high speed ${ }^{1-3}$.

There are different forms and brands of dental burs as well as commercial recommendations, detailed information about cleaning, disinfection and sterilization. However, data about the recommended number of uses is often unreported. Some authors such as Morrison and Corond ${ }^{8}$, report that the life of a dental bur is limited to no more than five or six sterilization cycles because it becomes distempered and loses its cutting edge, thus beginning to require greater working pressure with the consequent generation of heat and deleterious effect on the pulp. Sterilization of dental instruments, including burs, for reuse occurs regularly in all dental offices in order to minimize the risk of cross contamination between patients. The methods used for both cleaning and decontamination and for sterilization significantly reduce the durability and resistance of burs ${ }^{5,6}$.

Regarding the use of the rubber dam, some authors indicate that the rate of its usage by general dentists is $37 \%-43 \% \%^{7,8}$, while Siegel and von Fraunhofer ${ }^{9}$ report that $63 \%$ refer to using it. Another publication found that professionals with 5 to 10 years' work experience had the highest rate $(76.3 \%)$, while professionals with more than 20 years of practice had the lowest rate $(53.2 \%)$. Endodontists had the highest and most frequent use rate ${ }^{9}$.

Two different studies analyzed the behavior and attitudes of students from the United States of
America and health professionals in India regarding the use of different types of burs for tissue removal during caries treatment ${ }^{8,10,11}$, finding that most professionals in India preferred diamond burs, while students in different dental schools in the United States used tungsten carbide burs. In these studies, most dentists said they use the burs until they wear out $(85 \%)$, sterilize them once a day $(35 \%)$ or after each patient (35\%).

The aim of this study was to collect information about the habits of members of the dental community in Argentina regarding the use and conditioning of dentin removal burs in the treatment of carious lesions.

\section{MATERIALS AND METHODS}

A 14-item questionnaire was prepared in Google Forms platform, with an informed consent inserted at the beginning and anonymity set as selection criteria. Once validated in small groups, the relevant authorizations were processed and the questionnaire was sent to three lists of dental subscribers through the computer services area of the School of Dentistry, University of Buenos Aires, Argentina (FOUBA). According to information provided by the aforementioned area, the lists consisted of 8478 dentists, of whom 1555 were also faculty members and 27 were full professors. By the deadline for receiving responses, which was set as four weeks after the sending date, 294 replies were received. Data was analyzed by rates with $95 \%$ confidence intervals and chi-square test (significance level: $\mathrm{P}<0.05)$.

\section{RESULTS}

After four weeks, 294 replies were received, of which $47.93 \% \quad(42.18-53.68 \%)$ claimed to be members of faculty and $37.24 \%(31.68-42.81 \%)$ claimed to teach at FOUBA (Fig. 1).

Regarding area of specialization, most respondents reported disciplines related to the indispensable use of burs for caries treatment such as restorative dentistry, endodontics or prosthetic dentistry, as well as pediatric dentistry. 


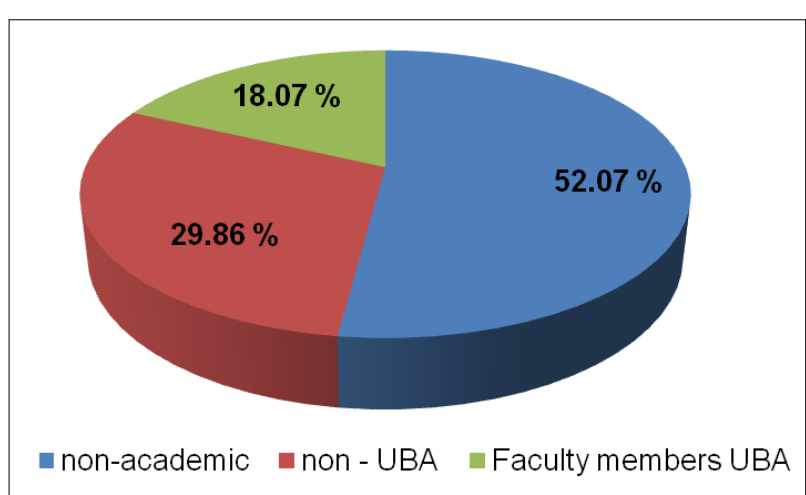

Fig. 1: Distribution of respondents by academic affiliation

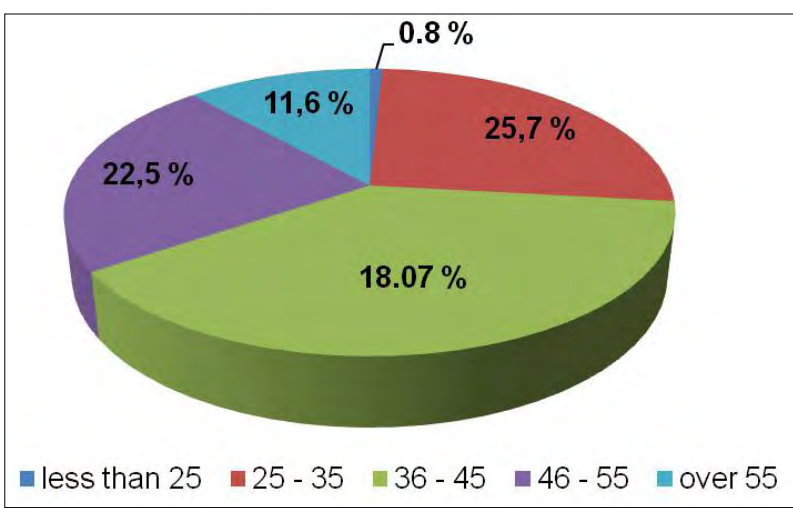

Fig. 2: Distribution of respondents according to their age
In terms of age, $26.90 \%(21.79-32.00 \%)$ reported being under 35 years old, $37.59 \%$ (32.01-43.16\%) 36 to $45,22.07 \%(17,30-26.84 \%) 46$ to 55 and $11.38 \%$ (7.72-15.03\%) over 55 years (Fig. 2).

About $22.07 \%$ (17.30-26.84\%) reported that they remove carious dentin with medium speed rotary instruments, while $32.76 \%$ (27.36-38.16\%) reported using super-high speed and $32.76 \%$ (27.36-38.16\%) a combination of both (Fig. 3). This item had significantly different responses as a function according to academic involvement $(\mathrm{P}<0,01)$. Around $31 \%$ (23.55\%-39.59\%) of the dentists who also identified themselves as faculty members claimed to employ medium speed, 20.59\% (13.93\%-27.97\%) ultra-high speed and $34.56 \%(26.21 \%-42.61 \%)$ both speeds. On the other hand, non-academic respondents answered $14.19 \%$, (9.00\%-20.87\%), 44.59\% (36.43\%-52.98\%) and $32.43 \%(24.98 \%-40.61 \%)$, respectively.

In terms of main use, removal of carious dentin was the most frequently mentioned. Among surveyed dentists, $68.07 \%$ (62.31\%-73.44) declared that they use round burs and $27.72 \%(22.60 \%-23.31 \%)$ associate round burs with another means. This was not found to depend on whether or not the respondents belonged to the academia $(\mathrm{P}>0.05)$.

Faculty members referred to using dental burs with absolute isolation always or almost always in $74.82 \%(67.60-82.04 \%)$ of the cases, while amongst respondents from outside the academic field, $51.01 \%$ $(42.98-59.03 \%)$ answered that they never or almost never do so $(\mathrm{P}<0.001)$ (Fig. 4).

Only $17.93 \%(13.52-22.35 \%)$ indicated that they keep a record of the number of times they use burs, while $50.34 \%(44.59-56.10 \%)$ of the respondents said that they use burs "until they no longer cut", and $23.79 \%(18.89-28.69 \%)$ of total respondents claim they use burs 1 to 5 times.
Table 1 summarizes the quantity and quality of devices and solutions claimed to be used during cleaning, decontamination and sterilization of burs. Overall, 98.27\% (96.77-99.77\%) said they clean their burs once used, $44.68 \%(38.80-50.70 \%)$ reported using three conditioning methods for burs, while $28.72 \%(23.50-34.40 \%)$ stated using two, and $19.15 \%(14.70-24.20 \%)$ four of them. Only about $4 \%$ selected only one $3.90 \%(2.00-6.90 \%)$ or five methods $3.55 \%(1.70-6.40 \%)$. The two most frequently selected single cleaning, decontamination or sterilization methods were metal brush, $94.33 \%$ (90.90-96.70\%) and enzymatic solution, 92.55\% (88.80-95.30\%). Of the $28.72 \%(23.50-34.4 \%)$ that selected 2 modes, mechanical brush, $96.30 \%$ (89.60$99.20 \%)$ and enzymatic solution, $88.89 \%$ (80.00$94.80 \%$ ) were the most frequently chosen methods to combine. Within the $44.68 \%(38.80-50.70 \%)$ that selected 3 modes, mechanical brush, $99.21 \%$ (95.70-100.00\%), enzymatic solution, $98.41 \%$ (94.40-99.80\%), autoclave, 34.92\% (26.60-43.90\%) and stove, $29.37 \%(21.60-38.10 \%)$ were the most frequently indicated to be used in association.

Of the $19.15 \%(14.70-24.20 \%)$ that selected 4 modes, metal brush, 98.15\% (90.10-100.00\%), enzymatic solution, $98.15 \% \quad(90.10-100.00 \%)$, autoclave, $\quad 51.85 \% \quad(37.80-65.70 \%)$, sodium hypochlorite, $40.74 \%$ (27.60-55.00) and stove, $38.89 \%(25.90-53.10 \%)$ were the most frequently indicated.

\section{DISCUSSION}

Although the removal of dentin affected by caries is one of the most frequent procedures in the daily practice of dentistry, the literature contains few studies about the attitudes of dental practitioners and faculty members regarding selection and 


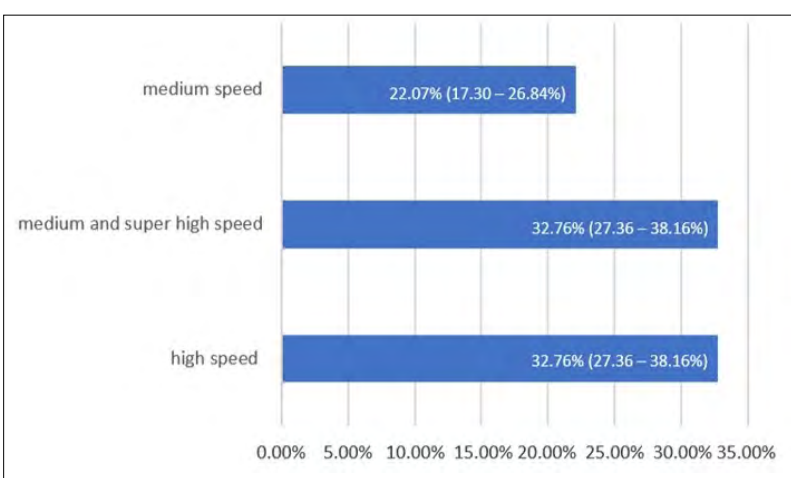

Fig. 3. Use of speeds reported by respondents

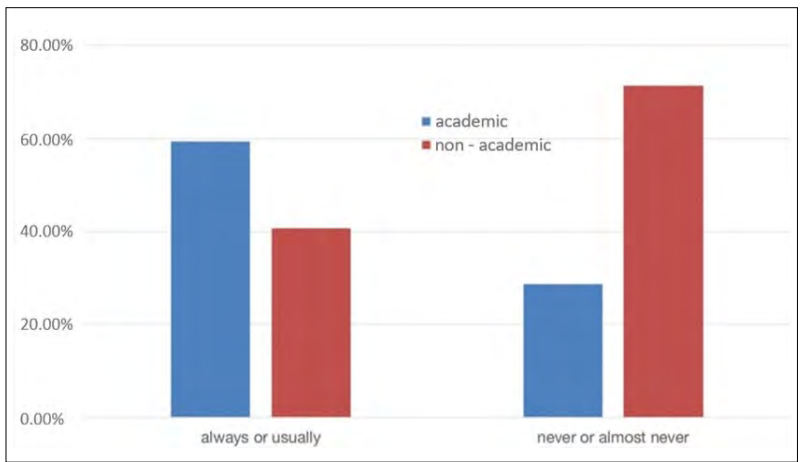

Fig. 4. Use of burs with absolute isolation reported by faculty members and non-academic dentists.

management methods of instruments used for removal of infected dentin. Of the dentists who responded the survey in this study, $97.28 \%$ said they clean or condition the burs, in contrast to $70 \%$ of the participants in the study by Sharma et $\mathrm{al}^{10}$. Regarding how many times a bur is used, although there is evidence in the literature that supports that an optimal limit is within five times, most of the respondents declared that they use them "until they no longer cut" in agreement with the paper by Sharma ${ }^{10}$ that explored the same variable in a group of Hindu dentists. With respect to the use of rubber dam, $62.1 \%$ of our respondents stated that they always or almost always use it, unlike the findings of Imberly and Carrico ${ }^{8}$, who indicate that $37-43 \%$ of dentists use it. A separate analysis comparing academic and non-academic respondents shows that the rates reported by nonacademics are similar to those found by Imberly and Carrico ${ }^{8}$. Metal brush and enzymatic solutions were the most frequently mentioned in one and two mode cleaning methods. When respondents referred to use three or more cleaning methods, stove, autoclave and ultrasound were the devices added to the protocols.

\section{CONCLUSIONS}

Most respondents state that they somehow condition the rotary instruments after use. About half of the respondents do not keep track of the number of uses and maintain that they use burs "until they no longer cut".

\begin{tabular}{|c|c|c|c|c|}
\hline chosen elements & single mode & two modes & three modes & four modes \\
\hline metal brush & $\begin{array}{c}94.33 \\
(90.90-96.70)\end{array}$ & $\begin{array}{c}96.30 \\
(89.60-99.20)\end{array}$ & $\begin{array}{c}99.21 \\
(95.70-100.00)\end{array}$ & $\begin{array}{c}98.15 \\
(90.10-100.00)\end{array}$ \\
\hline common brush & $\begin{array}{c}1.78 \\
(0.60-4.10)\end{array}$ & 0.00 & $\begin{array}{c}0.79 \\
(0.00-4.30)\end{array}$ & $\begin{array}{c}7.41 \\
(2.10-17.90)\end{array}$ \\
\hline enzymatic solution & $\begin{array}{c}92.55 \\
(88.80-95.30\end{array}$ & $\begin{array}{c}88.89 \\
(80.00-94.80)\end{array}$ & $\begin{array}{c}98.41 \\
(94.40-99.80)\end{array}$ & $\begin{array}{c}98.15 \\
(90.10-100.00)\end{array}$ \\
\hline alcohol & $\begin{array}{c}12.77 \\
(9.10-17.20)\end{array}$ & $\begin{array}{c}3.70 \\
(0.80-10.40)\end{array}$ & $\begin{array}{c}9.52 \\
(50.00-16.60)\end{array}$ & $\begin{array}{c}25.93 \\
(15.00-39.70)\end{array}$ \\
\hline sodium hypochlorite & $\begin{array}{c}17.08 \\
(12.90-22,00)\end{array}$ & $\begin{array}{c}3.70 \\
(0.80-10.40)\end{array}$ & $\begin{array}{c}9.52 \\
(5.00-16.60)\end{array}$ & $\begin{array}{c}40.74 \\
(27.60-55.00)\end{array}$ \\
\hline autoclave & $\begin{array}{c}28.01 \\
(22.80-33.60)\end{array}$ & $\begin{array}{c}1.23 \\
(0.00-6.70)\end{array}$ & $\begin{array}{c}34.92 \\
(26.60-43.90)\end{array}$ & $\begin{array}{c}51.85 \\
(37.80-65.70)\end{array}$ \\
\hline stove & $\begin{array}{c}23.76 \\
(18.90-29.20)\end{array}$ & $\begin{array}{c}4.94 \\
(1.40-12.20)\end{array}$ & $\begin{array}{c}29.37 \\
(21.60-38.10)\end{array}$ & $\begin{array}{c}38.89 \\
(25.90-53.10)\end{array}$ \\
\hline ultrasound & $\begin{array}{c}19.50 \\
(15.00-24.60)\end{array}$ & $\begin{array}{c}1.23 \\
(0.00-6.70)\end{array}$ & $\begin{array}{c}18.25 \\
(11.90-26.10)\end{array}$ & $\begin{array}{c}38.89 \\
(25.90-53.10)\end{array}$ \\
\hline
\end{tabular}

rates $(\mathrm{Cl95 \% )}$ 


\section{FUNDING}

None

\section{CORRESPONDENCE}

Dr. Hernan Tartacovsky

Cátedra de Odontología Restauradora, Facultad de Odontología, Universidad de Buenos Aires

Marcelo T. de Alvear 2142, Piso $9^{\circ} \mathrm{A}$,

(CP1122AAH) C.A.B.A., Argentina.

hernanjt@hotmail.com

various pre-cleaning methods. J Pak Med Assoc 2018; 68:1188-1192.

7. Gilbert GH, Litaker MS, Pihlstrom DJ, Amundson CW, Gordan VV, DPBRN Collaborative Group. Rubber dam use during routine operative dentistry procedures: findings from the Dental PBRN. Oper Dent 2010;35:491499.

8. Imbery TA Carrico CK. Dental dam utilization by dentists in an intramural faculty practice. Clin Exp Dent Res 2019;5:365-376

9. Siegel SC, von Fraunhofer JA. Dental burs--what bur for which application? A survey of dental schools. J Prosthodont 1999;8:258-263.

10. Sharma S, Shankar R, Srinivas K. An Epidemiological Study on the Selection, Usage and Disposal of Dental Burs among the Dental Practioner's. J Clin Diagn Res 2014;8:250-254.

11. Zou H, Li Y, Lian X, Yan Y, Dai X, Wang G. Frequency and Influencing Factors of Rubber Dam Usage in Tianjin: A Questionnaire Survey. Int J Dent 2016;2016:7383212. doi: $10.1155 / 2016 / 7383212$ 